\title{
Wepener, Cas
}

\section{University of Pretoria}

Müller, Bethel

Stellenbosch University ${ }^{1}$

\section{Water rituals as a source of (Christian) life in an African Independent Church: To be healed and (re)connected}

\begin{abstract}
African Independent Churches (AICs) are to large extent paperless churches. This means that for the biggest part liturgical documents does not exist and that a study of their worship must entail a study of their enacted rites which will include recordings and transcriptions of verbal expressions such as sermons. This article focuses on AIC worship in South Africa, with special attention to the role of so-called water rituals. In this article the main aim is an attempt to discern what the role of these water rituals are in the worship of this AIC and in the generation of social. Thus, after a description of the ritual data, the water rituals are analysed by making use of both anthropological and theological theory, especially the work of Mary Douglas and Gerhardus van der Leeuw.
\end{abstract}

\section{BACKGROUND AND INTRODUCTION²}

Many years ago, in the first half of the twentieth century, a mother living on a farm in what was then known as Zululand took her 12-year-old son to the community elders for help. The boy was very ill with a huge boil on his side and with no medical doctors around she did not know what to do. The elders decided to put the boy in a big pot filled with hot water. In the pot the boil burst and the boy fell into a faint that lasted for three days. When he woke up, he discovered that he was completely healed and at the tender age of twelve started to preach and teach God's message in the local community. ${ }^{3}$ In later years this boy became the founder of the Corinthian Church of South Africa (CCSA), which grew to become a large church within the collection of churches known as African Independent Churches (AIC). This particular story which incorporates both water and healing is well known in the CCSA as a denomination in which healing and water and also the two in combination are still central elements; to this day these two elements remain essential parts of their identity as Christians.

1. Dr. Cas Wepener (cas.wepener@up.ac.za) is Associate Professor of Liturgy and Homiletics at the Department of Practical Theology, Faculty of Theology, University of Pretoria, Pretoria, 0002, South Africa. Dr. Bethel Muller (bamuller@sun.ac.za) is emeritus Professor of Liturgy and Homiletics of the Department of Practical Theology, Faculty of Theology, University of Stellenbosch, Stellenbosch, 7600, South Africa.

2. This article was first presented as a paper at the 23rd Conference of Societas Liturgica in Reims, France which focussed on Baptism. This material is based upon work supported by the South African National Research Foundation (NRF) under Grant number 73974. Any opinion, findings and conclusions or recommendations expressed in this material are those of the authors and therefore the NRF does not accept any liability in regard thereto.

3. Information obtained from an interview with the widow of the founder of the CCSA and his daughter on 27/06/2011 in Weybank, Durban. 
In many congregations worldwide water is often used ritually in worship especially in relation to baptism, but also in other liturgical rituals such as baptismal remembrance and foot-washing services as well as for cleansing and healing. During field research in one CCSA congregation in Phepheni in the Eastern Cape Province in South Africa over the past four years, we counted no fewer than seven (groups of) rituals in which water is used for liturgical purposes. We are also fairly convinced, however, that future field work in this congregation and AIC denomination will reveal even more what we will call in this paper 'water rituals'. But before we name, describe and discuss these water rituals, let us first place them within the overarching framework of the larger research project of which this paper forms a part and make some observations on the methodology employed in our research.

Currently (2011) we are in the final year of a four-year research project funded by the South African National Research Foundation (NRF) operating under the title "Exploring the role of religious rituals in social capital formation for poverty alleviation". ${ }^{4}$ In present-day South Africa one of the major issues or challenges we face is poverty alleviation in which poverty is certainly viewed as the absence of material belongings, but much more than that, referring also, for example, to a spiritual level. ${ }^{5}$ Furthermore it has been argued that a missing link in social development is what has been referred to as social capital, a term we define as a combination of bonding, bridging and linking capital. Defining social capital in this way offers an inverse definition of poverty as the absence of bonding, bridging and linking capital, thus as the nonexistence of social capital. This implies that the generation of social capital can potentially contribute indirectly to poverty alleviation through the development of relationships in such a way that they can engender trust and function as a sort of glue that holds society together. ${ }^{6}$ And in a country such as South Africa, where religious organisations garner most trust from the country's citizens, ${ }^{7}$ where almost $80 \%$ of the population indicate that they belong to the Christian religion, and that $90 \%$ of persons between the ages of 18 and 35 attend a

4. For a general overview of the project and the main concepts see Cas J. Wepener et al., "The role of religious ritual in social capital formation. Theoretical and methodological points of departure of a South African exploration in progress," Religion \& Theology 17, nos. 1-2 (2010) 61-82; and for a description of how the research field was entered see Cas J. Wepener and Marcel Barnard, "Entering the field. Initiating Liturgical Research in an AIC," Acta Theologica 30/2 (2010) 192-210.

5. For a discussion of poverty and specifically also a broader definition of it as applied in this research project, cf. Henry Mbaya, "The socio-practical dimensions of isitshisa [burning of the heifer] in the Corinthian Church of South Africa," HTS Teologiese Studies/ Theological Studies 67/2 (2011) Art. \#930, 8 pages. doi:10.4102/hts.v67i2.930

6. For a more thorough description of the link between social capital formation, ritual and poverty alleviation, cf. Cas J. Wepener and Johan H. Cilliers, "Ritual and the generation of social capital in contexts of poverty," in Religion and Social Development in Post-Apartheid South Africa: Perspectives for Critical Engagement, Ignatius Swart et al. (eds.) (Stellenbosch: SUN Press, 2010); also in Rein Brouwer, Geloven in gemeenschap. Het verhaal van een protestantse geloofsgemeenschap, (Zoetermeer, Meinema, 2008)73-118. And for a more general discussion on research related to religion and social capital in South Africa see Ignatius Swart, "Religion and Social Capital Research in South Africa: Mapping an Agenda in Progress", in Titus Hjelm (ed.), Religion and Social Problems, Routledge Advances in Sociology Series (New York: Routledge, 2010) chapter 7. On congregations and social capital see Nancy, T. Ammerman, Congregation and Community, (New Brunswick/ New Jersey/ London: Rutgers University Press, 1997) 362-367. See also Anders Bäckström and Per Petterson (eds), Welfare and Religion in 21st Century Europe. Vol 1. Configuring the Connections, (Abingdon, Oxon UK: Ashgate, 2010).

7. Cf. Kate Lefko-Everett et al., "Reconciliation Barometer Survey Report" (Cape Town: Institute for Justice and Reconciliation, 2010), 5. 
NGTT: Oopbron - http://ngtt.journals.ac.za

worship service at least once a month ${ }^{8}$, the Christian liturgy can play, we believe, a potentially significant role in generating social capital. Building on this hypothesis, our overarching research question - which is also indirectly the question this paper addresses - is twofold, namely how to gain a better understanding of the way that liturgical rituals generate social capital, and how to actually use the liturgical rituals as a lens to gain a better understanding of social capital formation. As such this article thus not only aims at making a contribution to the field of Liturgical Studies, but also to the nascent debate regarding religion and development. James Wolfensohn for example also argues in his forward to a recent book on the topic for the importance of non-economic factors such as religion in development work. According to him religion suffuses all that people do and states that "Religion has an effect on many people's attitudes to everything, including such matters as savings, investment and a host of economic decisions." ${ }^{\prime 9}$ And one important aspect of religion is religious rituals, the main focus of the research project and also of this article.

Ritual makes use of ordinary physical material and events, but also of ordinary customs and traditions, based in culture and worldview in order to signify and point to spiritual realities, in general to the mystery of life. Rituals thereby manifest the basic ritual essence of being both mysterium tremendum et fascinans. They are powerful "rites of passage", pointing to a transition from the ordinary to the spiritual sphere, even from death to life, nourishing the day-to-day life of the individual and his or her community by acting on the different levels of being human.

Given this background on the repertoire of water rituals, rituals and social capital, religion and development as well as on the way in which rituals functions as a bridge between external reality and a deeper reality ${ }^{10}$, we now turn to one specific congregation participating in the research project and to some methodological considerations relevant to this article.

\section{The church in Phepheni and participatory observation}

For this specific article the authors conducted the field work themselves by means of participatory observation to collect the ritual data. ${ }^{11}$ In this process, firstly the baptismal

8. The statistics were obtained from Statistics SA, Population Census 2001, Religion Report, (Pretoria: SSA, 2004) also from Community Agency for Social Enquiry (CASE) research quoted by Nico Koopman, "Publieke Teologie in Suid-Afrika vandag. Die verhaal van die Beyers Naudé Sentrum vir Publieke Teologie" (Unpublished presentation: Stellenbosch, 2005); and cf. also Cas J. Wepener, "Liturgical research in a changing South African socio-cultural (liturgical) landscape: challenges and opportunities for method and theory," in Religion and Social Development in Post-Apartheid South Africa: Perspectives for Critical Engagement ed. Ignatius Swart et al (Stellenbosch: SUN Press, 2010). According to Wim Dreyer South Africa is on the top 10 list of countries worldwide with regards to attendance of worship services and, with an average of 56\%, fourth overall. Wim A Dreyer, Praktiese Ekklesiologie en bedieningspraktyk. Met verwysing na die Nederduitsch Hervormde Kerk van Afrika, (Ph.D. Dissertation: University of Pretoria, 2011) 95-96.

9. Cf. James D. Wolfensohn, "Foreword," in Religion and Development. Ways of Transformaing the World, ed. Gerrie ter Haar. (London: Hurst \& Co, 2011) xvii.

10. Cf. Gerard Lukken, Rituelen in overvloed. Een kritische bezinning op de plaats en de gestalte van het christelijk ritueel in onze cultuur, (Baarn: Gooi \& Sticht, 1999) 20. "Het heeft een grensoverschrijdende brugfunctie. Het verwijst naar een diepere werklijkheid, een verdere horizon, een ruimer landschap". Lukken here also refers to Goethe's definition of symbols, namely "The thing that is without being the thing still the thing".

11. Cf. Cas J. Wepener; Henry Mbaya and Marcel Barnard, "Worship in the Corinthian Church (AIC) of Phepheni, Eastern Cape, South Africa," Studia Liturgica for a discussion of the typical Sunday worship 
service on Easter Sunday 2011 was attended, participated in and described. Secondly, various semi-structured interviews were conducted with members and leaders of this congregation as well as with the widow and daughter of the late founder of the denomination. Lastly and very importantly, a focus group discussion was facilitated in which the main topic was water rituals in this congregation, both describing them and attempting to establish how those who participate in them also appropriate what they do. ${ }^{12}$

We will now describe the seven groups of water rituals and thereafter refer to theological and social anthropological theories which will help us to understand the relevance of these rituals in the light of the questions posed in the overarching research project.

\section{A Repertoire OF WATER RITUALS}

There are many more than seven individual groups of water rituals in this congregation, but in order to describe and discuss these rituals for our purposes, we will here group different kinds together. Thus we are referring to them as a ritual repertoire. ${ }^{13}$ The grouping is done with regards to the place, the time and the purpose of the various rituals.

\subsection{Cleansing rituals outside of the worship service}

The first type of water rituals are those connected to cleansing or purification, of which there are many kinds. In general these cleansing rituals are performed in the following way, the details of which vary, depending on the specific circumstances. Firstly and very importantly, these cleansing rituals are always performed outside the church building. The water that is used must be blessed by a priest before it can be used, otherwise it will not work, according to the priest. Then the water is sprinkled over the individual facing the person doing the sprinkling, including the head and feet; after that the person turns around and the same sprinkling is done on the back of his or her body; they turn around again and a bit of water is poured into their hands, which they then use to wash their hands.

This ritual or variations of it are performed in the following cases:

- $\quad$ All persons who have attended a funeral;

in this congregation as well as a demographic description of the village of Phepheni. For a general discussion of participatory observation cf. Earl R. Babbie and Johan Mouton, The Practice of Social Research, (Cape Town: Oxford University Press Southern Africa) 293-300; Carol A. Bailey, A guide to field research, (Thousand Oaks/ London/ New Delhi: Pine Forge Press, 1996); and for a specific application of the method of data collection cf. Clare V. Johnson, "Researching Ritual Practice," Studia Liturgica 35/2 (2005) 204-220; Martin D. Stringer, On the perception of worship, (Birmingham: Birmingham University Press,1999), as well as Cas J. Wepener, "Researching Rituals. On the use of participatory action research in liturgical studies," Practical Theology in South Africa 20/1 (2005) 109127.

12. Cf. with regards to the appropriation of a ritual by the participants see Paul Post, "Introduction and application. Feast as a key concept in a liturgical studies research design," in Christian Feast and Festival: The Dynamics of Western Liturgy and Culture, eds. P. Post et al., Liturgia condenda 12 (Leuven: Peeters Pers, 2001) 56-61. In general see Trevor Lloyd; James Steven and Philip Tovey (eds.) Social Science Research Methods in Contemporary Liturgical Research: An Introduction in Joint Liturgical Studies 69 (London: The Alcuin Club, 2010).

13. For the term 'ritual repertoire' see the repertoire of disaster rituals as reflected in the title of Paul Post et al., Disaster Ritual. Explorations of an Emerging Ritual Repertoire, Liturgia Condenda 15 (Leuven: Peeters Pers, 2003). 
NGTT: Oopbron - http://ngtt.journals.ac.za

- $\quad$ Someone who has touched a corpse;

- $\quad$ For a woman who gave birth (cf. Lev. 12);

- $\quad$ For a woman entering menopause;

- All persons who attended a court of law;

- A person who has sinned;

- A person coming out of prison;

- A boy returning from circumcision.

In some of these cases the water will also be mixed with ash obtained from the isitshisa ritual ${ }^{14}$, with blood of an animal or with the intestines of a chicken.

\subsection{Cleansing rituals in the worship service}

According to the three priests and some members during the focus group discussion, participants in the Sunday worship service sometimes have to be sprinkled with water when it happens that there are people possessed by bad spirits. By means of this sprinkling the bad spirits are thus expelled and, according to members, the person is also calmed down by drinking of the water. ${ }^{15}$

When the participants talked about the associations they have with water, or in conversations about the meaning of water and what the water does, the responses from both the interviews and the focus group were unanimous - "Water is closely related to cleansing". Cleansing as used in this ritual-liturgical context obviously does not refer to a literal cleansing, but refers to cleansing on another level, as the next ritual makes evident.

\subsection{Foot washing}

A standard part of the annual Good Friday service is the washing of the feet of all the members of the congregation by the priests. ${ }^{16}$ And when the members of the focus group in Phepheni tried to explain what cleansing entails they immediately referred to John 13 and Peter saying "then not only my feet..." It will be necessary to undertake an intensive study of the use of John 13 in this congregation in order to understand how exactly it functions in the use of this washing ritual.

14. The isitshisa or "burning of the heifer" refers to a sacrifice that is performed once or twice annually as part of a large worship service at the headquarters in Mlazi, a township just outside Durban, and of which the ashes are kept for ritual purposes.

15. There is a ritual related to funerals in Xhosa tradition called "To drink water" which is a metaphorical reference to calming people down who got a fright, although it does not involve the actual drinking of water, but rather the slaughtering of a sheep and a communal meal for the relatives of the deceased. The meal is supposed to 'calm' them after they were frightened as a family by the death of the family member and is therefore referred to as "To drink water". In some other cultures people are given sugar water after they got a fright and to calm them down. Cf. in this regard Cas J. Wepener, Van vas tot fees. ' $n$ Ritueel-liturgiese ondersoek na versoening binne Suid-Afrikaanse kultuurkontekste, (DTh dissertation: Stellenbosch University, 2004), 527.

16. Cf. Cas J. Wepener, “Snert. Ritual-liturgical measurements and recipes for social capital," Jaarboek voor rituele- en liturgische studies 25 (2009) 229-246. In general the ritual of foot washing worldwide takes place on Maundy Thursday. The practice here, however, is typical of AIC liturgy in general. 


\subsection{At the unveiling of the tombstone}

In some African cultures - such as among the Xhosa, a group of which most members in Phepheni are a part - there is a ritual for the unveiling of tombstones. During this service, which is comprised of many elements and of which the main purpose is the "taking home of the deceased person", ${ }^{17}$ water is also sprinkled on the tombstones and the explanation given is that this is done to prevent bad spirits that may later defile the tombstone by coming to the grave and taking the body away. The water ritual here is thus performed for the protection of the spirit of the deceased and to make sure that he or she can be safely brought home and re-connected to their family who are still alive. On Saturday evening 30 July 2011 a very special variation of this ritual took place in Durban, when by means of (amongst other things) performing this water ritual at the grave of the late son and successor of the founder of the CCSA, he was symbolically taken from his grave 'home' to his church in Mlazi, where he served as Archbishop of the CCSA after his father's death. ${ }^{18}$

\subsection{For healing}

Healing basically entails the restoration of the imbalances in an individual and societal sense. These imbalances and disorder experienced in person and in society sever the African from his/her place in the network of ubuntu as the basis of personal and communal life. Because illness is caused by a lack of total harmony, the principle of ordering life, healing has to be an integral part of experiencing this harmony with the life force (amandla). Again, in order to experience this life force, rituals are essential in man's search for salvation as balance in life.

Illness does not only affect the sick person, but also those who are related to this person. Therefore health is defined in terms of the fulfilment of all the roles expected of people in their society. The ancestors play a significant part in the restoration of these imbalances communication with them becomes possible through the performance of certain rites and rituals. ${ }^{19}$

The treatment of illness is therefore a deeply religious matter: the whole person is treated, the ailing body; the positive healing of the spirit under the influence of negative spiritual forces such as sorcery, witchcraft, possession of evil spirits; disobedience to ancestors or to the community in church and at home, or to God - affecting all relationships in life.

This "treatment" in moving towards healing is again embedded in the sacramental life of the individual and community, especially in the rituals of water as the source of life-giving force (amandla). In this regard there are numerous variations in how the water is used in liturgical rituals, such as the drinking of water, the sprinkling of water and immersion in water.

\subsection{At New Year}

Annually at New Year the whole congregation goes to the nearby river. As part of the worship

17. As explained by the widow and daughter of the founder of this church during an interview on $27 / 6 / 2011$ in Weybank, Durban and referring to the spirit of the deceased that is taken back from the grave to his or her home.

18. Information obtained from an interview with the widow of the founder of the CCSA and his daughter in Weybank, Durban on 27/06/2011.

19. See M. Vera Bührmann, "Religion and healing: the African experience" in Afro-Christian Religion and healing in Southern Africa. African Studies Vol 8, eds. G.C. Oosthuizen et al. (Lewiston: Edwin Mellen Press, 1989) 30. 
NGTT: Oopbron - http://ngtt.journals.ac.za

service at the river they go into the river and dip seven times into the water like Naaman in 2 Kings 5, according to one priest. And the explanation provided by members for the performance of this liturgical ritual? "There in the river we wash away all our worries from the Old Year to start the New Year afresh".20

\subsection{Baptism}

The seventh and last water ritual described here is the sacrament of baptism. ${ }^{21}$ This ritual consists of four separate parts that will here be described only very briefly, compared to the length of the overarching ritual process and compared to the enacted liturgical celebrations.

The first phase of this ritual is the so-called Ladi-service consisting of the lighting of candles in the home where a baby of parents who are members of the congregation is born. This Ladiservice must be performed 33 days after the birth of a boy and 66 days after the birth of a girl and is, according to one priest, closely connected to the Xhosa ancestral cult.

The second phase in the process of baptism is performed in the worship service and is performed roughly $1 \frac{1}{2}$ hours into the service after the call to worship, some circle dancing and Scripture reading, and a sermon. During the worship service on Easter Sunday 2011 a total of 12 babies and young children were baptized and the following actions occurred:

- $\quad$ The priest reads a formulary, which the researcher afterwards identified as a formulary coming from the African Congregational Church's book of worship;

- The secretary writes the names of all the children to be baptised in a book;

- $\quad$ The main priest and his wife ask the parents questions:

- $\quad$ 1st question (Rev. Dingaan): Are both parents here? Each time the answer was "No, the father is not here, but the grandmother is here also with 2 witnesses"

- $\quad$ 2nd question (Rev. Dingaan): Is this your child? He asks because, as he explains over and over, you cannot steal a child, since that is against the law;

- $\quad 3 r d$ question (Rev. Dingaan's wife): What have you read to them? Or a variation on the question was often: What portion of Scripture has been used to cleanse the child? And right after the question: "Why was this specific portion of Scripture chosen?"The answers regarding the choice of texts included Psalm 23, Isaiah 59, and Matthew 19. One reason provided, for example, when the mother said that she read Ps 23 was: "So that he will be successful in life". This questioning happens under the strict and scrutinising eyes of Rev. Dingaan's wife, who is not taking the whole procedure lightly and is clearly busy with a process of letting the mothers realise that baptism involves serious commitment;

20. During an interview with the founder's widow and daughter they pointed us to another and similar ritual: at the end of the July isitshisa in the early hours of the morning it is compulsory for all attending to bathe in the sea.

21. On baptismal rituals and customs in the AIC, see Gerhardus C. Oosthuizen, "Baptism \& healing in African Independent Churches" in Afro-Christian Religion and healing in Southern Africa. African Studies Vol 8, eds. G.C. Oosthuizen et al. (Lewiston: Edwin Mellen Press, 1989) 137-188. In general see Brian D Spinks, Reformation and Modern Rituals and Theologies of Baptism. From Luther to contemporary Practices, (Oxford: Ashgate, 2006). 
- Then Rev. Dingaan takes a glass of water from the table and hands it to his wife, who holds it in front of the grandmother, who places a silver coin in the glass. The glass is then handed back to Rev. Dingaan, who replaces the glass on the table.

- A packet of 6 candles is opened and one added to make a total of 7; Rev. Dingaan prays over them and hands them to his wife, who places one in the hands of the child/baby, the mother, the grandmother, the 2 witnesses and one for Rev. Dingaan's wife. She then lights all the candles whilst the congregation sings a hymn about the light of dawn.

- The mother then hands the child, who has a piece of cloth draped over his/her head, to Rev. Dingaan's wife, who removes the cloth and makes sure that the child's head is uncovered and then hands the child to her husband. Rev. Dingaan sticks his finger in the glass of water, and makes the sign of the cross on the child's forehead. Then he takes the glass of water and pours water from the glass on the child's forehead three times, whilst saying "In the name of the Father, Son and Holy Spirit". He pours quite a lot of water, so the babies always start crying. Then he firmly places his hand on the child's head and prays for the child quite earnestly;

- $\quad$ Rev. Dingaan's wife collects all the candles, which are still burning, and hands them to Rev. Dingaan, who extinguishes them by pushing them up into the air with a powerful gesture. This makes for a visually quite impressive ritual in the dark hut. After a candle has been extinguished, he places it on the table again. This is repeated several times until all the candles are back on the table;

- $\quad$ After all the baptisms another 2 circle dances are performed. There is a closing prayer after the door has been shut, with all the members' hands raised as they sing the Lord's Prayer for more than 10 minutes with closed eyes and very serious expressions on their faces;

- The service, which has lasted for more than 4 hours, is complete and Rev. Dingaan says that the secretary has just informed him that the baptismal certificates are ready for collection by the parents.

The third phase of the baptismal ceremony takes place at the river sometime after the church service. Afterwards (usually between one and two months) the whole congregation goes to the river in the mountain with the parents and the child(ren). There in the river at the waterfall Rev. Dingaan holds the baby and again pours the water three times over his/her head under the waterfall in the Name of the Father, Son and Holy Spirit. After this the parents have a feast at the church for everyone.

The fourth phase is actually more than a phase and is in fact a second baptism. Children who have been baptised as babies or young children are again baptised at the age of 18 in the river or in the sea. A similar service is held and the Trinitarian formula and immersion in the water are central to the ritual. One can thus say that this denomination baptises its members twice, once as babies/young children and once at the age of 18, but according to the leaders, baptism occurs only twice in the life of a member and no more than twice.

\section{Water Rituals - to Be healed And (RE-)COnNected}

Often in the ritual data the notion of cleansing (commonly referred to in the literature as purification) was given as the explanation for the performance of a particular water ritual. 
NGTT: Oopbron - http://ngtt.journals.ac.za

The necessity of water and specifically the ritual use of water to cleanse mean that something is thought to be dirty in some way or another in order for it to be in need of cleansing. The notion of dirt, of course, takes us to the work of Mary Douglas and in particular her book entitled Purity and Danger, 22 in which she defines dirt as "matter out of place", but also to some of the phenomenological and theological work of Gerhardus Van der Leeuw in his Sacramentstheologie from 1949 on the symbolic use of water.

Douglas's definition of dirt as "matter out of place" is in opposition to more modern concepts of dirt that have more to do with hygiene and fear of illness. She elaborates on the notion of dirt being matter out of place to show that such a definition implies "a set of ordered relations and a contravention of that order" ${ }^{\prime 23}$ and that "where there is dirt there is system". ${ }^{24}$ It then follows that there is a symbolic relationship between dirt and a system of purity. Douglas explains that the ways in which humans and societies behave towards dirt or "matter out of place" is derived from the fact that dirt is "likely to confuse or contradict our cherished classifications". 25 Those things in society that do not fit our ordered systems and classifications are potential "powers and dangers" that can threaten our sense of order, according to Douglas, and thus "Ritual recognises the potency of disorder". 26 Society does not know how to cope with marginalised and borderline cases with respect to its system of order. Rituals are consequently performed to keep these unclassifiable phenomena at bay, for example, the rite de passage for someone in a transitional state. ${ }^{27}$ Rituals of purity and taboo relating to dirt are thus important in upholding a certain social structure. In Phepheni it seems as if water rituals play a particularly important role in this regard, as will be illustrated in the conclusion.

In his Sacramentstheologie ${ }^{28}$ Van der Leeuw describes the role of cleansing and purification on account of "dirt" caused by conditions of illness, all forms of ill-luck, adversity, evil, all elements that threaten life, especially evil spirits. Dirt is something that belongs to the rubbish and refuse dump of life. The ritual of cleansing is more than "mere" cleansing or washing; it has a 'liferenewing effect'. Van der Leeuw states that "cleansing signifies the giving of new life, renewal of life... as a matter of fact regeneration". ${ }^{29}$ He then refers to the general phenomenological uses of water rituals in old Roman customs (associated with the festival of lustrum = lavo or washing) and to February as the month of washing (februar = the cleansing of utensils). In Christianized Europe holy fountains were converted into baptismal fonts. This even appears

22. Mary Douglas, Purity and Danger. An analysis of concepts of pollution and taboo (London / New York: Routledge, 2007, reprinted from 1966); cf. also Jan van Wiele, 'Mary Douglas' Purity and Danger revisited', in Jaarboek voor liturgie-onderzoek 23 (2007) 177-209.

23. Mary Douglas, Purity and Danger 44; cf. also the application of Douglas's insights with regards to commensality in this congregation in Cas J. Wepener, "Snert. Ritual-liturgical measurements" (2009).

24. Mary Douglas, Purity and Danger 44.

25. Ibid., 45.

26. Ibid., 117.

27. Douglas's explanations here are closely related to the work of Van Gennep and Turner on transitional rites. Cf. Arnold van Gennep, 'Territorial passages and the classification of rites', Readings in Ritual Studies, ed. Ronald, L. Grimes (Upper Saddle River, NJ: Prentice Hall, 1996) 529-536; Victor W. Turner, 'Betwixt and Between: The Liminal Period in Rites de Passage,' in Reader in Comparative Religion. An Anthropological Approach eds. William A. Lessa and Evon Z. Vogt (New York: Harper \& Row Publishers, 1965); Victor W. Turner, The Ritual Process. Structure and Anti-Structure (London: Routledge \& Kegan Paul, 1969); Victor W. Turner, 'Passages, Margins and Poverty: Religious Symbols of Communitas', in Worship 46/7 (1972) 390-412.

28. Gerhardus Van der Leeuw, Sacramentstheologie (Amsterdam: HJ Paris, 1949).

29. Ibid., 172; see also 176. 
in Shakespeare's spiritually disturbed Lady Macbeth performing a ritual washing of her hands.

The pollution by "dirt" can only be removed by ritual, in the case of the individual as well as the community. When the water is blessed, this ritual receives sacramental and healing power. This not only stresses the phenomenological but also the theological viewpoint: water in itself has no sacramental cleansing power; it must be blessed and "ordained" in the liturgy of the community and its culture. It is therefore interesting to note how water functions in the mythological background of many cultures: as a sort of archetype, both of chaos and death, on the one hand, and new life, on the other. This new life emerges from the amniotic fluid at birth. Therefore water has such dynamic sacramental power in the life of the individual and the community. In the ritual use of water it becomes powerful in the sacramental life of the individual and his community, where the sacrament and sacramentalia are eventually empowering the primary and fundamental form of living in the fullest and most balanced sense.

According to Ronald Grimes: "Cured, you are fixed; healed, you are reconnected".30 And Douglas's notion of dirt being matter out of place and her theory that rituals of purity and taboo help to uphold a certain system, along with the insights of Van der Leeuw, closely relate to Grimes's definition of ritual healing. Cleansing is needed in order to connect or re-connect someone, which is to a large extent synonymous with being healed. The social systems to which an individual is connected through water rituals as performed by the Corinthian Church of Phepheni are firstly traditional Xhosa culture as signified by the Ladi-service. Water rituals, however, are performed at various stages in a person's life cycle it seems, for example, a boy after returning from initiation and also at the unveiling of the tombstone, these are examples that are closely related to connecting people to Xhosa traditional culture and keeping them connected even after they have passed on. Secondly, several water rituals also connect a person to the Corinthian Church of SA as a denomination as well as to the particular congregation of Phepheni. In this regard baptism, as described in this paper, is a primary example of connection, but various other water rituals, such as the different uses of cleansing rituals, are used to reconnect people again after they have been disconnected for some or other reason. Lastly and referring to, for example, the water ritual at the unveiling of the tombstone, some of these rituals also serve to reconnect a deceased person to his home and family on a spiritual level, but also sometimes to the CCSA as such too, as the one example indicated. To end this discussion of healing and (re-)connecting via water rituals as pertaining to social and ecclesial groups alone would be reductive. This healing and (re-)connection also relates to a notion that can only be sufficiently explained by means of theological categories. In order to explore this further we once again turn to Van der Leeuw and his Sacramentstheologie.

Van der Leeuw describes symbols (sum-ballein) as the coincidence of two realities; by the combination of sign and having significance a reality is summoned on a second, deeper level. This has the creative power to affect something on this second level. ${ }^{31}$ Therefore the symbol must be repeated over and over. ${ }^{32}$ Van der Leeuw distinguishes between the biblically instituted and ordained sacraments and the so-called sacramentalia as sacramental actions in the context of liturgy whereby rituals such as cleansing, healing, blessing, dances and

30. Ronald L. Grimes, Deeply into the bone. Re-inventing rites of passage, (Berkeley/ Los Angeles/

London: University of California Press, 2000) 343.

31. Van der Leeuw, 1949, 8f.

32. Ibid., 254. 
NGTT: Oopbron - http://ngtt.journals.ac.za

processions have a "sacramental substratum".33 They are liturgical acts, next to but integrally connected to Word and sacrament. In the sacramental character of life, both sacrament and sacramentalia function in a very close connection. Sacramentalia therefore become, together with the main sacraments, essential parts of God's regenerative and recreative work in the individual and the community. In sacrament and sacramentalia people find their fullest and most radical expression of being human. We can thus say that there is also a bridging in and through these liturgical rituals between humans and God, in this church and congregation also, and importantly the group and God, but also between individuals and themselves via a liturgical ritual in which the Spirit of God is active.

Of particular interest are Van der Leeuw's remarks on the ritual of dancing - dance being the oldest form of art, but also the oldest ritual. ${ }^{34}$ In dance and gesture, movement is demonstrated as the essence of life: "life is movement." ${ }^{35}$ Through the inherent movement in dances and processions, sacramental life is generated in its fullest sense. According to Van der Leeuw the dance is also epiclesis and calls for the adventus Dei. To quote him in this regard: "God beweeg zich...En Hij zette ons op deze aarde in beweging...Het is het begin van zijn werk in schepping en verlossing. Het is ook het begin van de dans." ${ }^{136}$ This is an important insight for this research, because most if not all of the liturgical rituals described earlier are accompanied and also enveloped by much dancing.

Baptism is much more than an initiation into a church community - as in most Western Churches, especially those of the Reformed tradition. Also, and especially in the African Independent Churches it signifies a way of life in the search for salvation as wholeness and well-being. Christian life in the AIC is baptismal life, life embedded in the sacrament. In some churches baptism often functions merely as a sign or as a part of a religious social system. But in the AIC it is regarded as an effectual sacrament, as a sacramental induction into the body of Christ. In a performative way it is effectual in changing the baptised person in the fullest sense of the word: it is part of the process of growing into the practice of the Christian life. Through baptism the individual is healed, blessed, restored, given power (amandla), given the Spirit in order to overcome the ever-present and abiding evil spirits and forces, including those of poverty and as such the absence of social capital. ${ }^{37}$ Children have to be baptized not only to participate in the covenant of God with the parents, but also and in principle to obtain this power, to share in the amandla, and to keep the evil spirits away. For the AICs baptism symbolizes that the life of sin and the realm of evil have been broken. Note here how anthropology and tradition are integrated into a new order of life, living in a new community of the baptized. And to a large extent this happens throughout a person's life in the CCSA by being connected and re-connected by means of the ritual use of water. In a very specific sense the baptismal theory and practice of baptism in the AIC make a valuable contribution to the ecumenical discussion of baptism - a contribution not always accepted.

Before we conclude, some final remarks related to the ritual use of water more generally in AICs in South Africa are necessary. Water mythology is not strange to the African tradition and

\section{Ibid., 257.}

34. See fully Van der Leeuw, G. Wegen en Grenzen, Amsterdam: HJ Paris, 1953. We are aware of the fact that not all scholars of ritual view dance as a ritual.

35. Van der Leeuw, 1949, 206.

36. Ibid., 82.

37. Cf. for an argument in this regard Cas J. Wepener and Johan H. Cilliers, "Ritual and the generation of social capital", 43-44. 
sacramental experience - Zulu tradition has it that the first human being came out of a bed of reeds growing by a pool of water. ${ }^{38}$ In baptism life is given through purification, washing in the water of the pool or river or at the seaside, or by means of sprinkling. Baptism symbolises the life lived at the pool (ichibi). At the pool or in the sea or in the sprinkling of water the baptized person receives power from the water, which also has a cleansing and healing effect. The preparation for baptism requires fasting, attending a revival service (umvusilelo) and confession of sins. This once more reminds us of the practice in the old church emphasizing the necessity of spiritual preparation for receiving the holy sacrament and the emphasis on preparation during the catechumenate. Of importance is also the praying over the water, whereby a spell is placed on the water to give it a life-giving force. One of the main reasons for the remarkable growth of the AIC movement is the fact that these churches succeed in integrating African culture, customs and traditions with Christianity. Often living in a hostile environment, especially one in the process of urbanisation and secularisation, they experience these adverse forces so strongly that they have to perform rituals, often following traditional lines such as divining and the use of water, but now adapted and streamlined for new situations. Thereby rituals help them to cope with the disorder and the lack of harmony they experience in the totality of life, personal and communal. Oosthuizen notes that these adaptations have a "miraculous effect when correctly utilized". ${ }^{9}$ This is clearly demonstrated and manifested in their ritual uses of water in drinking, sprinkling, washing, immersing and also in baptism. These rituals are mostly based on and strengthened by the use of water.

A close look at these water rituals and attendance of them, the data obtained from the focus group interview and various other interviews, as well as the theological and social anthropological work, led us to the conclusion that these rituals function in the congregation in Phepheni to heal, to connect and to re-connect, all three of which are closely related to each other.

\section{Water RITUALS BOth AS LENSES AND GENERATORS OF SOCIAL CAPITAL}

Our journey through the data, the theology and the anthropological theories brings us back once again to the initial question and objective of the NRF project, namely the potential of ritual to act as both a generator of, and lens for, social capital formation. We start with the latter point.

The description and analysis of water rituals in the congregation and community of Phepheni made invisible borders more visible, especially with regards to the opposition of clean versus unclean or dirty. If social capital is defined as a combination of bonding, bridging and linking, then attempts to generate social capital in this community without taking cognisance of these borders will be doomed to fail, or even worse be potentially harmful in this community. These borders are also intrinsically related to the spiritual web typical of African cultures. According to Mbiti, African religion is so integrated into people's lives that it is virtually impossible to draw a line between the secular and the religious, making it clear that African religion has formed the world view of the continent's inhabitants. ${ }^{40}$ In this world view in which the material

38. Oosthuizen et al., Afro- Christian Religion and Healing 148.

39. Oosthuizen et al., Afro- Christian Religion and Healing 82. See also Bengdt G M Sundkler, Bantu

Prophets in South Africa, (London: Oxford University Press, 1961) 255 and Martin West, Bishops and

Prophets in a Black City, (Cape Town: David Phillip, 1975).

40. Cf. John S. Mbiti, “'Hearts Cannot be Lent!' In Search of Peace and Reconciliation in African

Traditional Society," The Princeton Seminary Bulletin XX/1 (1999) 2. 
NGTT: Oopbron - http://ngtt.journals.ac.za

and spiritual world coincide there is a longing for equilibrium, which is for various reasons often disrupted by, for example, pollution. The longing for equilibrium and also for peace reaches also to the spiritual sphere, and hence the balance and peace between the physical and spiritual worlds must be maintained and in this regard rituals are very important.

This (re-)connecting that becomes more apparent by means of a study of water rituals is aimed at this world, but thus also reaches into the spiritual realm and should be appreciated as such when there is talk about bonding, bridging and linking in this congregation and community. Bonding, bridging and linking between the living, however important, cannot be fully achieved in separation from bonding and bridging with the living dead. It therefore seems that water rituals are indispensible for these kinds of borders to be crossed in this community and are thus indeed already functioning as generators of social capital. Here we can experience how the whole of life, health and total wellbeing of the individual and community are embedded in the sacramental life. In the symbolic sacrament of renewal of life, in the resultant victory over life-estranging evil forces, the emphasis is placed on the rebirth of people and their community. And a large part of this renewal depends upon the healing power of a repertoire of water rituals, connecting and re-connecting people throughout their lives and in the hereafter. These rituals are thus indeed generators of social capital, but even more so they are also generators of spiritual capital.

It seems that, whenever a 'boil' develops in this congregation and church denomination, the wisdom of the elders in using water to promote healing is still adhered to.

\section{KEY WORDS}

Worship

Ritual

African Independent Church

Social Capital

Participatory Observation

\section{TREFWOORDE}

Liturgie

Ritueel

Afrika Onafhanklike Kerk

Sosiale Kapitaal

Deelnemende Observasie

\section{Contact Details/Kontakbesonderhede}

Cas Wepener; Bethel Müller

Prof; Prof

University of Pretoria; Stellenbosch University

South Africa

cas.wepener@up.ac.za; bamuller@sun.ac.za

0124203157; 0847175723 